УДК 796.035

DOI https://doi.org/10.26661/2663-5925-2021-3-03

\title{
ВПЛИВ ЗАНЯТЬ ІЗ ПЛАВАННЯ НА ФУНКЦІОНАЛЬНИЙ СТАН ДИХАЛЬНОЇ СИСТЕМИ СПОРТСМЕНІВ ВІКОМ 13-16 РОКІВ ІЗ ДЦП
}

Ключові слова: ДЦП, плавання, підлітки, дихальна система, заняття.

\section{Калашнік I. К.}

\author{
аспірант
}

Запорізький національний університет

вул. Жуковського, 66, Запоріжжя, Украӥна

orcid.org/0000-0002-4365-6961

kalashnikirc@gmail.com

За останні роки дитячий церебральний параліч став одним із найбільш поширених захворювань нервової системи в дітей. Ця недуга належить до невиліковних хвороб, проте проведення своєчасної і правильної корекції ушкоджених систем організму дітей за допомогою корекційних фізичних вправ, застосування елементів спортивних ігор і спеціальних рухових режимів $є$ передумовою для успішної побутової, навчальної, трудової та соціальної адаптації дітей до реальних умов життя, їх інтеграції в суспільство.

Проаналізовано спеціалізовану літературу щодо впливу занять із плавання на організм підлітків та науково-методичну літературу про стан здоров'я підлітків, що хворі на ДЦП. Проведено оцінку рівня функціональних показників дихальної системи підлітків віком 13-16 років із ДЦП. Експериментально доведено пріоритетність використання занять із плавання для підвищення рівня показників функціонального стану дихальної системи підлітків із ДЦП. Дослідження було проведене в серпні 2021 р. на базі басейну «Мотор Січ» та Інклюзивноресурсного центру по Вознесенівському району міста Запоріжжя Департаменту освіти і науки Запорізької міської ради. У дослідженні брали участь 20 підлітків - дві групи по 10 осіб (експериментальна та контрольна групи). В експериментальну групу увійшли підлітки з ДЦП, які професійно займаються плаванням, а в контрольну - підлітки 3 ДЦП, які займаються тільки лікувальною фізичною культурою та інколи проходять курси масажу. На початковому етапі дослідження підлітки за віковими й анатомо-фізіологічними особливостями майже ідентичні. Усі підлітки були обстежені в однакових умовах.

Значення показників функціональних проб системи дихання підлітків із дитячим церебральним паралічем свідчать про те, що в разі систематичних занять із плавання в підлітків збільшується життєва ємність легень. Частота дихання зменшується майже вдвічі, що свідчить про правильне глибоке дихання. Результати проби Штанге показали, що підлітки з ДЦП, які займаються плаванням, затримують дихання після повного вдиху на 28 секунд більше, ніж ті, хто не займається плаванням. Після проведення проби Генчі також були отримані результати, які підтверджують користь занять плаванням для дихальної системи підлітків із ДЦП. Отримані результати свідчать про те, що заняття з плавання допомагають розвитку функціональних можливостей дихальної системи в підлітків із ДЦП. 


\title{
INFLUENCE OF SWIMMING CLASSES ON THE FUNCTIONAL CONDITION OF THE RESPIRATORY SYSTEM OF ATHLETES AGED 13-16 WITH CEREBRAL PALSY
}

\author{
Kalashnik I. K. \\ Postgraduate Student \\ Zaporizhzhia National University \\ Zhukovskoho str., 66, Zaporizhzhia, Ukraine \\ orcid.org/0000-0002-4365-6961 \\ kalashnikirc@gmail.com
}

Key words: cerebral palsy, swimming, adolescents, respiratory system, classes.
In recent years, cerebral palsy has become one of the most common diseases of the nervous system in children. This disease is one of the incurable diseases, but timely and correct correction of damaged systems of children, with the help of corrective exercise, the use of elements of sports games and special motor modes, is a prerequisite for successful domestic, educational, labor and social adaptation to real living conditions, their integration into society.

Specialized literature on the impact of swimming lessons on the body of adolescents and scientific and methodological literature on the health of adolescents with cerebral palsy were analyzed. The level of functional indicators of the respiratory system of adolescents aged 13-16 years with cerebral palsy was assessed. The priority of using swimming lessons to increase the level of indicators of the functional state of the respiratory system of adolescents with cerebral palsy has been experimentally proven. The study was conducted in August 2021 on the basis of the pool "Motor Sich" and the Inclusive Resource Center in the Voznesenovsky district of the city of Zaporizhzhia of the Department of Education and Science of the Zaporizhzhia City Council. The study involved 20 adolescents - two groups of 10 people (experimental and control groups). The experimental group included adolescents with cerebral palsy who are professionally engaged in swimming, and the control group included adolescents with cerebral palsy who are engaged only in therapeutic physical training and sometimes undergo massage courses. At the initial stage of the study, adolescents are almost identical in age and anatomical and physiological features. All adolescents were examined under the same conditions.

Determination of indicators of functional trial respiratory systems of adolescents with cerebral palsy showed that with systematic involvement in swimming in adolescents increases the vital capacity of the capacity of legends. Respiration rate is reduced by almost half, which indicates proper deep breathing. The results of the Barbell study showed that adolescents with cerebral palsy who were involved in breathing support after a full breath for 28 seconds less than those who were not involved in the passage. After Genchi tests also received results that confirm the benefits of a plan for the respiratory system contractors with cerebral palsy. The results suggest that involvement in swimming helps to develop the functionality of the respiratory system in adolescents with cerebral palsy.
Постановка проблеми. У роботі необхідно розглянути та довести позитивний вплив плавання на дихальну систему підлітків із дитячим церебральним паралічем. Плавання - це один із найбільш складних координаційних видів діяльності людини, і розвивати ці фізичні якості краще
3 дитинства. Систематичні заняття плаванням сприяють формуванню правильної постави, прищеплюють гігієнічні навички, гартують організм, підвищують його опірність різним простудним захворюванням, сприяють зміцненню здоров'я, розвитку витривалості $[3 ; 5 ; 9]$. 
Позитивний вплив плавання чинить i на дихальну систему організму, тренує дихальні м'язи та підсилює стійкість організму проти дії мікроорганізмів. Дихання пов'язує людину 3 навколишнім світом.

За останні роки дитячий церебральний параліч став одним із найбільш поширених захворювань нервової системи в дітей. Ця недуга належить до невиліковних хвороб, проте проведення своєчасної та правильної корекції ушкоджених систем організму дітей за допомогою корекційних фізичних вправ, застосування елементів спортивних ігор і спеціальних рухових режимів $є$ передумовою для успішної побутової, навчальної, трудової та соціальної адаптації дітей до реальних умов життя, їх інтеграції в суспільство.

Уміння правильно дихати під час різного фізичного навантаження підвищує фізичну працездатність, покращує обмін речовин, допомагає відновленню мови. У разі ДЦП дихання слабке, поверхневе, рухи погано співвідносяться 3 диханням, багато осіб страждають на порушення вимови, що пов'язано з відсутністю правильної постановки дихання. Тому навчання правильного дихання є засобом не лише оздоровлення, а й вирішення низки реабілітаційних завдань. У дитини, навченої глибокого правильного ритмічного дихання, легше відбувається розслаблення м'язів тулуба, що сприяє іiі навчанню правильних рухів i вимови $[1 ; 4 ; 7]$.

Розлади дихання під час ДЦП часто залежать від недостатності центральної регуляції дихання та від патології опорно-рухової системи. Це виражається в порушенні ритму і глибини дихання, у розладі координації між артикуляцією та диханням. Певну роль при цьому відіграє порушена іннервація у вигляді одночасного напруження м'язів-антагоністів. Так, затримка напруження діафрагми разом із м'язами, які відповідають за вдих, утруднює видих. В іншому випадку може підвищитися частота дихання, тоді після вимовленого слова хворий повинен зробити судорожний вдих. У деяких випадках порушення дихання можуть спостерігатися незалежно від мовлення, проте в момент розмови ці розлади посилюються. Особливо страждає активний видих. Оволодіння активним видихом, типами дихання та мовним диханням - це основне завдання, одним із засобів вирішення якого є плавання [6;8].

Як плавання впливає на стан дихальної системи?

По-перше, плавець робить вдих і видих, долаючи опір води, при цьому тренується дихальна мускулатура, збільшується рухливість грудної клітини. Тиск води перешкоджає виконанню вдиху, що приводить до розвитку м'язів, які розширюють грудну клітку. Тиск води на грудну клітку сприяє також більш повному видиху, покращуючи газообмін. Водночас під час видиху у воду доводиться долати їі опір, а це також приводить до підвищеного навантаження на дихальну мускулатуру та іiі розвитку.

По-друге, під час плавання витрачається багато енергії, а отже, зростає потреба в кисні. Тому організм прагне максимально повно використовувати кожен вдих. У результаті систематичних плавальних тренувань ростуть показники дихальної системи (удосконалюється дихальний ритм, підвищується еластичність легень, зростає кількість альвеол легень, збільшується обсяг і вентиляція легень, максимальне споживання кисню).

У разі регулярних занять плаванням виробляється досконалий тип дихання. Дихання плавця більш глибоке, є менш частим. Доросла людина, яка не займається плаванням, у спокої виконує 14-16 дихальних циклів на хвилину, тоді як плавець - 7-8 циклів на хвилину. Перевага такого сповільненого темпу дихання полягає в тому, що легені та інші органи дихання встигають добре відпочити, отримати повноцінне харчування, а їх знос сповільнюється (схожа ситуація також з уповільненням пульсу).

У результаті тренування органів дихання підвищується еластичність легень, збільшується число альвеол, зростає обсяг легень.

У людей, які займаються плаванням, резервні можливості системи дихання вдвічі чи втричі вищі, ніж у людей, які не займаються спортом. Особи, які не одержують регулярне фізичне навантаження 3 працею, можуть набрати в легені 2-3 літри повітря, тоді як плавці - 5-7 літрів.

Альвеоли плавця працюють ефективно, тому організм добре забезпечується киснем під час вдиху та легко звільняється від вуглекислого газу під час видиху.

Максимальне споживання кисню (далі - МПК) є одним із найбільш надійних показників фізичної працездатності людини. МПК є показником аеробної продуктивності організму, тобто здатності виконувати тривалу роботу невисокої інтенсивності (плавання й біг на довгі дистанції, заняття на велотренажері тощо). МПК - це та найбільша кількість мілілітрів кисню, яку людина здатна споживати протягом 1 хвилини. У людини, яка не займається спортом, МПК 3200-3500 мл/хв, натомість у плавців МПК досягає 6000 мл/хв. МПК залежить від маси тіла (особливо маси працюючої мускулатури), віку, статі, генетичних факторів, стану системи транспорту кисню, рівня фізичної підготовленості людини. У нетренованих людей МПК на 1 кг маси тіла дорівнює в середньому 40 мл, а у плавців сягає 70-80 мл.

По-третє, під час плавання в диханні беруть участь найвіддаленіші ділянки легень, а тому в 
них виключаються застійні явища. Включення у процес дихання зазвичай малозадіяних частин легеневої тканини дає змогу уникнути їх передчасної старечої атрофії та багатьох захворювань дихальної системи.

По-четверте, систематичне пірнання та плавання із затримкою дихання підвищують стійкість організму до гіпоксіі. Це підтверджують результати досліджень багатьох науковців $[4 ; 10 ; 11]$.

Метою роботи $\epsilon$ вивчення позитивного впливу занять із плавання на функціональний стан системи дихання в підлітків із дитячим церебральним паралічем.

Для досягнення цієї мети необхідно було виконати такі завдання:

1) оцінити функціональний стан дихальної системи дітей із ДЦП;

2) визначити вплив занять із плавання на дихальну систему підлітків, що хворі на ДЦП;

3) експериментально довести ефективність застосування занять із плавання для підлітків, хворих на ДЦП.

У роботі використані такі методи досліджень, як аналіз та узагальнення науково-методичних літературних даних, клінічні методи дослідження (зокрема, для визначення частоти дихання, визначення життєвої ємності легень проведені проби Штанге та Генчі). Усі отримані дані оброблені за допомогою математичного та статистичного методів.

Організація дослідження. Дослідження було проведене в серпні 2021 р. на базі басейну «Мотор Січ» та Інклюзивно-ресурсного центру по Вознесенівському району міста Запоріжжя Департаменту освіти і науки Запорізької міської ради. У дослідженні брали участь 20 підлітків - дві групи по 10 осіб (експериментальна й контрольна групи). В експериментальну групу увійшли підлітки 3 ДЦП, які професійно займаються плаванням, а в контрольну - підлітки з ДЦП, які займаються тільки лікувальною фізичною культурою та інколи проходять курси масажу. На початковому етапі дослідження підлітки за віковими й анатомо-фізіологічними особливостями майже ідентичні. Усі підлітки були обстежені в однакових умовах.

Результати дослідження. Щоб виміряти різницю в показниках дихальної системи, було проведено низку тестів, які можуть достовірно оцінити різницю у функціональному стані та роботі дихальної системи підлітків із ДЦП, які брали учать у дослідженні.

Так, проба Штанге реєструє час затримки дихання під час глибокого вдиху. Виконується вона так: після 5 хвилин відпочинку випробовувані в положенні сидячи роблять 2-3 глибокі вдихи й видихи, а потім, зробивши глибокий вдих, затримують дихання. У момент першого вимушеного видиху, неможливості подальшої затримки дихання припиняється вимірювання часу.

Проба Генчі реєструє час затримки дихання після повного видиху. Виконується вона так: після 5 хвилин відпочинку випробовувані в положенні сидячи роблять 2-3 глибокі вдихи й видихи, а потім, зробивши повний видих, затримують дихання. У момент першого вимушеного вдиху, неможливості подальшої затримки дихання припиняється вимірювання часу.

Частота дихання - це число дихальних рухів (циклів «вдих - видих») за одиницю часу (зазвичай хвилину). Вона є одним 3 основних і найстаріших біомаркерів. Підрахунок числа дихальних рухів здійснюється за кількістю переміщень грудної клітини та передньої черевної стінки.

Життєва ємність легень є одним 3 основних показників стану дихальної системи. Це максимальна кількість повітря, що видихається після найглибшого вдиху. У нормі життєва ємність легень становить близько $3 / 4$ загальної ємності легень та характеризує максимальний обсяг, у межах якого людина може змінювати глибину свого дихання. Вимірюється вона приладом, що має назву «спірометр». Так, підлітки отримують спірометр (шкала спірометра показує 0 мл), потім проводять 2-3 вдихи й видихи, а далі виконують максимально глибокий вдих i, взявши в рот мундштук трубки спірометра, рівномірно, тривало видихають у нього повітря до відмови. Повітря не має виходити між губами та через ніс. Дослідження проводиться 2-3 рази, записується найкращий результат. Дані відображаються на шкалі спірометра в мілілітрах.

Дані всіх вимірів під час проведення тестів дихальної системи в експериментальній i контрольній групах підлітків із ДЦП наведені в таблиці 1.

Таблиця 1

Показники дихальної системи підлітків із ДЦП

\begin{tabular}{|l|c|c|}
\hline \multicolumn{1}{|c|}{ Показники } & $\begin{array}{c}\text { Контрольна } \\
\text { група }\end{array}$ & $\begin{array}{c}\text { Експеримен- } \\
\text { тальна група }\end{array}$ \\
\hline $\begin{array}{l}\text { Життєва ємність } \\
\text { легень (мл) }\end{array}$ & $1600 \pm 73,2$ & $2450 \pm 95,6$ \\
\hline $\begin{array}{l}\text { Частота дихання } \\
\text { (разів) }\end{array}$ & $17 \pm 2$ & $8 \pm 1$ \\
\hline $\begin{array}{l}\text { Проба Штанге } \\
\text { (с) }\end{array}$ & $21 \pm 3,3$ & $49 \pm 2,2$ \\
\hline Проба Генчі (c) & $9,5 \pm 2,1$ & $17 \pm 1,8$ \\
\hline
\end{tabular}

Під час проведення тесту життєвої ємності легень середній результат у контрольній групі

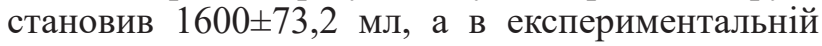




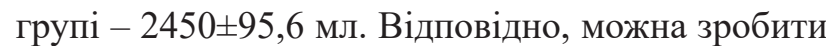
висновок, що середній результат у плавців із ДЦП на 850 мл кращий, ніж у підлітків, які не займаються плаванням.

Після проведення тесту на частоту дихання було виявлено, що підлітки, які займаються плаванням, роблять на 9 актів дихання на 1 хвилину менше, ніж звичайні підлітки: результати в контрольній групі становлять $17 \pm 2$, в експериментальній $-8 \pm 1$.

Унаслідок оцінювання результатів функціональних проб Штанге та Генчі виявлено, що середні результати плавців становили 49 $\pm 2,2$ с (проба Штанге) та $17 \pm 1,8$ с (проба Генчі), а в підлітків, які не займаються плаванням, $-21 \pm 3,3$ с та 9,5 $\pm 2,1$ с відповідно. Отже, проба Штанге у плавців на 28 с краща, ніж у підлітків, які не займаються плаванням, а проба Генчі - на 7.5 с відповідно.

Висновки та перспективи подальших досліджень. Значення показників функціональних проб системи дихання підлітків із дитячим церебральним паралічем свідчать про те, що в разі систематичних занять із плавання в підлітків збільшу- ється життєва ємність легень - під час проведення експерименту була виявлена різниця між показниками у 850 мл. Частота дихання у плавців зменшується майже вдвічі, що свідчить про правильне глибоке дихання. Результати проби Штанге показали, що підлітки з ДЦП, які займаються плаванням, затримують дихання після повного вдиху на 28 секунд більше, ніж ті, хто не займається плаванням. Після проведення проби Генчі також були отримані результати, які підтверджують користь занять плаванням для дихальної системи підлітків із ДЦП, - затримка дихання після повного видиху в підлітків із ДЦП, які займаються плаванням, на 7,5 с довша. Отримані результати свідчать про те, що заняття 3 плавання допомагають розвитку функціональних можливостей дихальної системи в підлітків із ДЦП, тому можемо рекомендувати спортивне плавання як один із найбільш вдалих видів спорту для таких підлітків.

Надалі необхідно дослідити вплив занять із плавання на інші системи організму підлітків із ДЦП, що й стане предметом подальших досліджень.

\section{ЛІТЕРАТУРА}

1. Єдинак Г.А. Теорія і технологія використання фізичних вправ у реабілітація дітей з церебральним паралічем : навчальний посібник для студентів вищих навчальних закладів III-IV рівнів акредитації. Кам’янець-Подільський : ПП Мошак М.I., 2007. 352 с.

2. Гойда Н.Г., Бережний В.В., Мартинюк В.Ю. Першочергові заходи удосконалення дитячої реабілітації в неврології. Харків : Форт, 1993. 56 с.

3. Ван дер Стам Б. Допомога дитині при церебральному паралічі. Практичні поради. Львів : Місіонер, 1995. $72 \mathrm{c}$.

4. Хрущев С.В., Симонова О.И. Физическая культура детей с заболеваниями органов дыхания : учебное пособие для студентов высших учебных заведений. Москва : Издательский центр «Академия», 2006. $304 \mathrm{c}$.

5. Основи медико-соціальної реабілітації дітей з органічними ураженнями нервової системи / за ред. В.Ю. Мартинюка, С.М. Зінченко. Київ : Інтермед, 2005. 416 с.

6. Мурза В.П. Фізична реабілітація : навчальний посібник. Київ : Олан, 2004. 558 с.

7. Мухін В.М. Фізична реабілітація : підручник. Київ : Олімпійська література, 2000. 422 с.

8. Гидротерапия: роль погружения в воду и физических упражнений в ней / А.Т. Быков, Т.Н. Маляренко, В.П. Терентьев и др. Физкультура в профилактике, лечении и реабилитации. 2009. № 1. С. $30-42$.

9. Глазирін І.Д. Плавання : навчальний посібник. Київ : Кондор, 2006. 502 с.

10. Чем полезно плавание для организма. Сайт о плавании. URL: http://plavaem.info (дата звернення: 27.08.2021).

11. Шульга Л.М. Оздоровче плавання : навчальний посібник. Київ : Олімпійська література, 2008. 232 с.

\section{REFERENCES}

1. Yedynak, H.A. (2007). Teoriia i tekhnolohiia vykorystannia fizychnykh vprav u reabilitatsiia ditei z tserebralnym paralichem: navchalnyi posibnyk dlia studentiv vyshchykh navchalnykh zakladiv III-IV rivniv akredytatsii [Theory and technology of using physical exercises in the rehabilitation of children with cerebral palsy: a textbook for students of higher educational institutions of III-IV levels of accreditation]. Kamianets-Podilskyi: Private entrepreneur Moshak M.I. [in Ukrainian].

2. Hoida, N.H. et al. (1993). Pershocherhovi zakhody udoskonalennia dytiachoi reabilitatsii v nevrolohii [Priority measures to improve pediatric rehabilitation in neurology]. Kharkiv: Fort [in Ukrainian].

3. Van der Stam, B. (1995). Dopomoha dytyni pry tserebralnomu paralichi. Praktychni porady [Helping a child with cerebral palsy. Practical advice]. Lviv: Misioner [in Ukrainian]. 
4. Khrushchev, S.V., Simonova, O.I. (2006). Fizicheskaya kul'tura detey s zabolevaniyami organov dykhaniya: uchebnoe posobie dlya studentov vysshikh uchebnykh zavedeniy [Physical culture of children with respiratory diseases: textbook for students of higher educational institutions]. Moscow: Akademiya [in Russian].

5. Martyniuk, V.Yu., Zinchenko, S.M. (eds.) (2005). Osnovy medyko-sotsialnoi reabilitatsii ditei z orhanichnymy urazhenniamy nervovoi systemy [Fundamentals of medical and social rehabilitation of children with organic lesions of the nervous system]. Kyiv: Intermed [in Ukrainian].

6. Murza, V.P. (2004). Fizychna reabilitatsiia: navchalnyi posibnyk [Physical rehabilitation: textbook]. Kyiv: Olan [in Ukrainian]

7. Mukhin, V.M. (2000). Fizychna reabilitatsiia: pidruchnyk [Physical rehabilitation: textbook]. Kyiv: Olimpiiska literatura [in Ukrainian].

8. Bykov, A.T. et al. (2009). Gidroterapiya: rol' pogruzheniya v vodu i fizicheskikh uprazhneniy v ney [Hydrotherapy: the role of immersion and exercise in water]. Fizkul'tura $v$ profilaktike, lechenii $i$ reabilitatsii, no. 1, pp. 30-42 [in Russian].

9. Hlazyrin, I.D. (2006). Plavannia: navchalnyi posibnyk [Swimming: textbook]. Kyiv: Kondor [in Ukrainian].

10. Chem polezno plavanie dlya organizma [Why swimming is beneficial for the body]. Swimming website. Retrieved from: http://plavaem.info [in Russian].

11. Shulha, L.M. (2008). Ozdorovche plavannia: navchalnyi posibnyk [Health swimming: textbook]. Kyiv: Olimpiiska literatura [in Ukrainian]. 